\title{
Hands Off!
}

\section{How Organizational Design Can Make Delegation Credible}

Foss, Kirsten; Foss, Nicolai Juul

Document Version

Final published version

Publication date:

2005

License

CC BY-NC-ND

Citation for published version (APA):

Foss, K., \& Foss, N. J. (2005). Hands Off! How Organizational Design Can Make Delegation Credible. Institut for Strategic Management and Globalization. SMG Working Paper No. 5/2005

Link to publication in CBS Research Portal

\section{General rights}

Copyright and moral rights for the publications made accessible in the public portal are retained by the authors and/or other copyright owners and it is a condition of accessing publications that users recognise and abide by the legal requirements associated with these rights.

\section{Take down policy}

If you believe that this document breaches copyright please contact us (research.lib@cbs.dk) providing details, and we will remove access to the work immediately and investigate your claim. 


\title{
Hands Off! How Organizational Design Can Make Delegation Credible
}

\author{
Kirsten Foss \\ Nicolai J. Foss \\ SMG WP 5/2005
}

October 2005 
SMG Working Paper No. 5/2005

September 2005

ISBN: 87-91815-05-3

Center for Strategic Management and Globalization Copenhagen Business School

Porcelænshaven 24

2000 Frederiksberg

Denmark

www.cbs.dk/smg 


\title{
Hands Off! How Organizational Design Can Make Delegation Credible
}

\author{
Kirsten Foss \\ Center for Strategic Management and Globalization \\ Copenhagen Business School \\ Porcelænshaven 24, $2^{\text {nd }}$ fl; 2000 Frederiksberg; Denmark \\ kf.smg@cbs.dk \\ Nicolai J. Foss \\ Center for Strategic Management and Globalization \\ Copenhagen Business School \\ Porcelænshaven 24, $2^{\text {nd }}$ fl.; 2000 Frederiksberg; Denmark \\ njf.smg@cbs.dk \\ and \\ Department of Strategy and Management \\ Norwegian School of Economics and Business Administration \\ Breiviksveien 40; N-5045; Bergen; Norway
}

First version 22 February 2002; this version 17 October 2005

\section{Acknowledgments}

We are grateful to Richard Burton, Bruno Frey, Oliver Gottschalg, Anna Grandori, Ammon Salter, Oliver Williamson, and Sidney Winter for comments on earlier versions of this paper. Seminar audiences at Copenhagen Business School and Université Paris I (Sorbonne), Université Paris X (Nanterre), and Southern Denmark University, and participants at the 2005 DRUID conference in Copenhagen also provided highly useful inputs.

Key words: Employee motivation, managerial intervention, credible delegation, organizational structure, coordination mechanisms. 


\title{
Hands Off! How Organizational Design Can Make Delegation Credible
}

\begin{abstract}
Credible delegation of discretion obtains when it is a rational strategy for managers not to overrule employee decisions that are based on delegated decision rights or renege on the level of delegated discretion (and this is common knowledge). Making delegation of discretion credible becomes a crucial issue when organizations want to sustain the advantages that may flow from delegation: Such advantages are dependent on motivated employees, and managerial overruling or reneging is harmful to motivation. However, little work has been done on how organizations can make delegation credible. We argue that key elements of organizations (i.e., organizational structure, coordination mechanisms, reward structures, and interdependencies between activities) and how these fit influence the credibility of delegation. Fit configurations of organizational elements reduce the probability of managerial intervention that may harm employee motivation. This introduces a neglected incentive dimension to the organizational design literature. Moreover, it is argued that harmful intervention may be reduced by increasing managers' costs of intervening. Refutable propositions are derived.
\end{abstract}




\section{Introduction}

How can delegation be made credible? That is, how can managers make it credible to employees that they will not renege on agreements to delegate discretion (i.e., decentralize decisions) to those employees? Making delegation credible becomes a crucial issue when organizations want to sustain the advantages that can flow from delegation, such as increasing the motivation to solve complex tasks (Gagné and Deci 2005: 346) (e.g., innovation, cf. Osterloh and Frey 2000), and securing adaptation by making faster and more effective use of local knowledge (Galbraith 1995). Such advantages depend upon employee motivation; however, employees that are overruled or have discretion diminished will likely suffer a loss of motivation (e.g., Robinson and Rousseau 1994). They will contribute less effort and creativity, in work and problemsolving to the organization. The more organizational value-creation depends on an extensive delegation of discretion to employees — as is particularly likely in organizations where a substantial number of employees are knowledge workers —, the more important is the issue of credibility.

In somewhat different guises, the issue of delegation of discretion has become increasingly prominent in various organizational discourses, such as the organizational behaviour field (Thomas and Velthouse 1990), agency theory in organizational economics (e.g., Jensen and Meckling 1992), the "new organizational forms" literature (e.g., Osterloh and Frey 2000; Child and McGrath 2001; Foss 2003), and in parts of the recent literature on the multinational corporation (e.g., Birkinshaw 1997). However, save for a few contributions (notably Baker, Gibbons, and Murphy 1999), the credibility of delegation has not been addressed. The purpose of this paper is to frame this issue in the context of organizational theory. Thus, the central contention in what follows is that key organizational elements - notably organizational structure, coordination mechanisms, and interdependencies between activities — influence the credibility of delegation. In particular, the fit between these organizational elements influences the credibility of delegation, as more fit configurations will reduce the probability of managerial intervention that can harm employee motivation. 
Insights from organizational theory and the organizational economics primarily drive this argument. Classical contributions to the organizational design literature (contingency theory and configurational approaches) (Thompson 1967; Lawrence and Lorsch 1967; Galbraith 1974, 1995; Mintzberg 1983; Van de Ven and Drazin 1985; Burton and Obel 1988, 2004; Meyer et al. 1993) supply the fundamental understanding of such organizational elements as organizational structure, coordination mechanisms and interdependencies. Organizational economics supplies the following inputs: From Jensen and Meckling (1992) comes the idea that delegation of discretion introduces a tradeoff between the benefits of better utilization of local knowledge and the costs from loss of control. Baker, Gibbons and Murphy (1999) offer a basic framing of the notion of credible delegation that we reformulate. Williamson's $(1985,1996)$ idea of the “impossibility of selective intervention" is related to the main argument here, as is Burton and Obel's (1988) experimental investigation of how organizational forms (i.e., the M-form) can constrain opportunism. We also make use of insights that are more in the organizational behaviour mould, such as Rousseau's (1989) work on psychological contracts and Osterloh and Frey's (2000) discussion of the relation between motivation and organizational form. The present paper is thus in the spirit of Gibbons' (1999) call for more interaction between, on the one hand, psychologically and sociologically grounded organizational theory, and, on the other hand, economics perspectives on organizations (cf. also Kaplan and Henderson 2005).

We begin by defining key terms, such as delegation of discretion, and then analyze the organization level costs and benefits of delegating discretion (“Organizational Costs and Benefits of Delegating Discretion”). Defining managerial intervention as a reduction in discretion delegated to employees, we discuss how such intervention cause loss of employee motivation and reduce organization level value creation ("Managerial Intervention and Employee Motivation"). This raises the issue of how delegation of discretion can be made credible, preserving employee motivation. We build a simple model to frame the issue and encapsulate the definitions and literature review of the preceding sections ("Credible Delegation"). Using the insights of the model, we then discuss how organizational elements and particularly the fit between these help to make 
delegation credible (“Credible Delegation through Organizational Design”). Finally, we offer thoughts on the contribution of this work and how it may be taken further ("Concluding Discussion”).

\section{Organizational Costs and Benefits of Delegating Discretion}

\section{Defining Delegated Discretion}

Specialization in an organization is accompanied by some degree of delegation, because any organizational division of labour must imply the delegation of rights to use or commit at least some organizational resources. While organizations always increase delegation when they increase specialization, they do not necessarily increase delegation of discretion. Organizations can delegate well-defined activities that leave hardly any discretion to employees. ${ }^{1}$ In other words, a (hypothetical) completely standardized job where all the tasks involved in the job are exhaustively described would imply delegation but not discretion. ${ }^{2}$ At the other extreme, organizations can delegate the very processes of defining the problems to be worked on, that is, choosing, structuring, decomposing and solving the relevant problems (cf. Simon 1962, 1973, 1991; Nickerson and Zenger 2004).Clearly, this leaves much discretion to employees, particularly when the problems are complex ones. There are many intermediate levels of delegation of discretion in between these extremes. In sum, discretion obtains when a set of choices are left to the agent.

Delegation of discretion is constrained by technological and organizational factors. Perhaps most fundamentally, discretion is influenced by (job and unit) specialization; thus, increasing the number of tasks in a job over which the employee can exercise discretion sacrifices specialization advantages. The nature of the technology itself may constrain discretion; for example, there may be few discretionary choices to make with respect to operating an extremely specialized machine that can only be used in a certain way and at a

\footnotetext{
${ }^{1}$ Thus, Taylorism was essentially about maximizing specialization in order to minimize discretion for workers

${ }^{2}$ Delegation of use rights to assets is fully compatible with an authority relation in which an employer orders the employee to carry out certain activities in a pre-determined manner (Simon 1991). Delegation of use rights does not necessitate discretion. However, discretion can be delegated in authority relations. For example, the employee can be delegated discretion to meet goals or to carry out plans in any way that he sees as feasible and preferable. In agency relations (which can be employment relations), there is always delegation of discretion, since the agent is supposed to act in the interest of the principal (the employer), using his own knowledge and judgment.
} 
certain stage of the production process. In addition to such technological factors, delegation of discretion depends on organizational variables, notably on coordination mechanisms. Mintzberg (1983) identifies mutual adjustment, direct supervision, planning of work processes, goal-planning, and skill standardization as the generic coordination mechanisms. They are typically supplemented with budgets, transfer prices, quotas and other restrictions that help higher-level managers control and ration the use of organizational resources, as well as goals and plans that serve to direct lower level resource commitment and work activities into coherent patterns. Moreover, coordination is supported by reward systems, control-, information-, and decision procedures (Grandori 2001). There is a rather direct link from such mechanisms to the delegation of discretion. Thus, different coordination mechanisms are associated with different levels of delegation of discretion; implementing specific coordination mechanisms translates into implementing certain levels of delegation of discretion. Thus, mutual adjustment and goal planning are the coordination mechanisms that allow for the greatest degree of discretion with respect to coordination of work activities, while rigorous work flow process planning allows for the least degrees of delegation of discretion. ${ }^{3}$ However, in addition to the above technological and organizational factors, the choice of how much discretion to delegate is also influenced by expected organizational benefits and costs that stem from the changed behaviours that increasing the delegation of discretion will cause.

\section{Organizational Benefits of Delegating Discretion}

A classic argument in favour of delegating discretion is the high costs of making centralized decisions when an organization is facing an environment characterized by relatively rapid and unpredictable changes (Burns and Stalker 1961; Galbraith 1974). The costs of transmitting information within the hierarchy, the risk of managerial overload, and the losses from lagging decision-making may become prohibitive in dynamic environments. Knowledge and information may be utilized more efficiently by letting those who possess relevant local information also make local decisions (Jensen and Meckling 1992).

\footnotetext{
${ }^{3}$ Although mutual adjustment in principle allows for the implementation of the highest degrees of discretion, this is not always the case. For example, a mutual adjustment process may be a process of well-defined consultation situations in which complementary pieces of information are brought together in order to select one element of a set of well-defined actions and with well-defined criteria for selection, leaving very limited discretion (Casson 1994)
} 
Discretion is arguably also delegated in an attempt to influence employee motivation, intrinsic as well as extrinsic (Porter and Lawler 1968; Deci 1975; Gagner and Deci 2005). In particular, delegation of discretion has often been linked to intrinsic motivation, particularly in the context of complex tasks that require creativity in problem-solving and in the context of certain types of sharing behaviour, such as knowledge sharing (e.g., Hill and Amabile 1993; Baron and Kreps 1999: 98; Osterloh and Frey 2000). Thus, Mintzberg (1983: 97) argues that "[i]n general creative and intelligent people require plenty of room to manoeuvre." and Osterloh and Frey (2000: 543) points out that delegation “... raises the perceived self-determination of employees and therewith strengthens intrinsic motivation" (Osterloh and Frey 2000: 543), leading to an increase in creativity in the pursuit of goals. Reducing the "room to manoeuvre" or "self-determination" through reducing discretion can be expected to reduce motivation (Kreps and Baron 1999).

Issues relating to extrinsic motivation enter to the extent that delegation of discretion makes it possible for the employee to more directly control his rewards through controlling his efforts This may come about in various ways: First, having more discretion can make it easier to reach the performance goals for which rewards are paid. Second, reaping private benefits may become easier, for example, because on-the-jobconsumption can be increased. ${ }^{4}$ Third, employees may be able to upgrade their human capital in a more focuse manner, allowing them to reap higher benefits later.

\section{Organizational Costs of Delegating Discretion}

In the economics of organization, optimum delegation is sometimes framed as depending on the trade-off between agency costs and the benefits from increased and better use of local knowledge in decision making. Thus, Jensen and Meckling (1992) postulate that organization-level costs caused by the agency problem are a positive, monotonous function of the degree of delegation in a organization (ceteris paribus). Agency costs

\footnotetext{
${ }^{4}$ A "private benefit" is here defined as some present or future utility that flows to the agent because of a specific action that the agent undertakes to realize this utility and which is not part of the compensation paid by the organization to the agent.
} 
rise to the extent that employees who are given more freedom also reduce the level of effort they choose or because they choose the wrong activities. ${ }^{5}$

In addition to agency costs, the costs of delegation of discretion include costs stemming from reduced coordination of interdependencies within the organization (Galbraith 1974). Coordination is a reciprocal modification of behaviour among members of an organization in order to reach desired ends in an effective manner (Grandori 2001). The need for coordination arises, because there are interdependencies between activities and the actions of organizational members. Interdependencies emerge when decisions call for the use of knowledge and information possessed by different members of the organization, when organizational members carry out work activities that are physically interconnected, and when there are complementarities among the effort levels exerted by organization members. An increase in the delegation of discretion may result in coordination problems, such as product cannibalization, actions that are out of sync with the actions of other employees (Roberts 2004), and overuse of common pool resources (Vining 2003).

Delegation of discretion makes sense as long as the organizational benefits in terms of increased and/or improved use of local knowledge and improvements in employee motivation exceed the costs in terms of agency costs, coordination costs and costs resulting from attempts to remedy these problems (e.g. managerial intervention, extensive use of mutual adjustment processes, influence activities and investment in buffer capacity). The efficient amount of delegation in an organization is determined where the (discounted) marginal costs are balanced against (discounted) marginal benefits of delegation of discretion. Whether such an optimum is sustainable depends, inter alia, on managerial intervention.

\section{Managerial Intervention and Employee Motivation}

\section{Managerial Intervention}

Managerial intervention is here defined as a particular manifestation of authority (Simon 1951), namely as those managerial acts that effectively reduce the discretion that is delegated to an employee. Such

${ }^{5}$ Even if motivation is increased because of delegation, agency costs may rise if intrinsically motivated employees choose an activity that is inoptimal (from the point of view of the organization). 
intervention may take two forms. First, it can amount to over-ruling employee decisions that have been made on the basis of delegated decision rights. Second, it can be a matter of reducing the level of discretion that is delegated to employees, for example, by substituting or complementing mutual adjustment and goal planning with direct supervision or detailed work plans, or by restricting budgets, increasing control activities and making use of more detailed business plans and goals. Both types of intervention are effectively instances of reneging on an implicit contract to delegate.

Managerial intervention may be exercised in an attempt to eliminate or reduce the costs that typically arise from coordination failures in organizations with an extensive delegation of discretion. As such, intervention would seem to be a low cost means of eliminating coordination failures (Coase 1937; Malmgren 1961; Foss 2001). However, the actual costs of intervention go beyond the use of managerial resources: A huge organizational behaviour literature suggests that both extrinsic and intrinsic employee motivation may be badly harmed by managerial intervention. For example, Heath et al. (1993) argue that in an employee relationship, employees develop implicit and explicit expectations to the contract governing the relationship, and particularly to the benefits that they believe they deserve under the implicit contract, that is, their "entitlements." Such expectations may be represented by "status quo" points, that is, what employees believe are their entitlements. The discretion that is delegated to employees may become part of their perceived entitlements. In general, negative motivational consequences can be expected to follow from managerial intervention that interferes with employee entitlements; reneging on delegation/overruling arguably is an instance of such interference.

Similar conclusions may be derived from the literature on psychological contracts which also predicts negative motivational effects of managerial intervention that is perceived of by employees as being unfair, arbitrary, and in other ways break with established psychological or implicit contracts. For example, Rousseau and Parks (1993: 36) argue that “... contract violation erodes trust [and] undermines the employment relationship yielding lower employee contributions (e.g. performance and attendance) and lower employer investments (e.g., retention, promotion)." Empirical work has reached similar conclusions 
(Robinson 1996; Foss 2003). In sum, serious organizational costs may be caused by managerial intervention to the extent that reduced employee motivation and reduced employee trust in management reduce efforts and investments in employee human capital.

\section{Complex Links between Intervention and Motivation}

Managerial interventions can be classified as taking place for "good causes" or for "bad causes". While the former refers to managerial intervention that is intended to benefit the organization, the latter refers to harmful sub-goal pursuit (Williamson 1993). While relatively clear cut in practice, it may often be difficult to place actual managerial practice unambiguously in one of the two categories, not the least for those employees that are subject to intervention. For example, managers may delegate substantial discretion to employees in an attempt to rejuvenate the organization. Employees, happy with their new increased discretion, come up with profit-improving ideas about how to improve products, processes, etc., and many of their ideas are implemented. Management then decides that the organization already is now fully occupied with implementing the ideas; as a consequence, the level of delegated discretion is reduced, because for the need costly idea-generation is smaller.

Absent consideration of motivational effects, such an intervention may appear to be value-creating. However, motivational effects may likely kick in, and destroy value because decreased motivation leads to lower effort supplied to the organization and reduced investments in organization-specific human capital. The motivational loss is caused by employees perceiving of the intervention as breaking with explicit promises to delegate discretion, and this may foster "moral outrage" (Parks 1997). Even if employees recognize the intervention as being undertaken for the sake of the organization, motivation may still be harmed, for example, because of the manner in which the intervention is undertaken. Managerial attempts to somehow compensate employees post intervention may only make matters worse (Deci 1975).

Although managerial intervention is quite likely to harm employee motivation, the links between intervention, and motivation and, in turn, organizational value creation are highly complex and unpredictable. In particular, complexity and unpredictability is introduced because employees cannot always 
accurately determine if intervention is for the benefit of the organization or only for the benefit of the manager and because their assessment of an intervention may strongly influence their motivation. Thus, even if managers have incentives to take employee motivation into account, this may prove very difficult to do in a case by case manner. ${ }^{6}$

The aim here is not to disentangle the complex causal chain between intervention, motivation, and organizational value creation, but rather to argue that for motivational reasons (and ultimately for reasons of organizational value creation) organizations face a need to make delegation credible. In fact, it is precisely because the causal connections between intervention, motivation, and organizational value creation are complex and unpredictable that it is crucial to make delegation credible. Imagine that management had perfect knowledge of these connections. It would then be possible to precisely assess the motivational consequences associated with any intervention, and calculate the impact on organizational value creation. Given this, only value-increasing intervention would be performed. In fact, intervention could be "fine-tuned" to reach the maximum organizational value-creation. Intervention that reduced organizational value creation would be avoided and intervention that promoted such value creation would be undertaken. However, such a "first-best" situation is in general not attainable, because of the problem of predicting the effects on employee motivation of intervention. An important implication is that at least some opportunities for value-creating intervention that would obtain in a situation of full information must be forsaken; thus, some inefficiency is unavoidable. However, while the "first-best" solution cannot be reached, organizations may aim at reaching a "second-best" solution where intervention is reduced to a level where value creation is maximized subject to the constraints represented by motivation loss and the need for adaptability. ${ }^{7}$

\footnotetext{
${ }^{6}$ The links between motivation and effort/human capital investments (and ultimately organizational value creation) are also likely to be highly complex and unpredictable. A classical argument that because of the complex and illunderstood nature of the causal structure between a policy intervention and its effects, policy-makers should stick to rigid rules was developed by economist Milton Friedman (1960).

${ }^{7}$ This line of reasoning is closely related to Oliver Williamson's (1985: Chpt. 5; Williamson 1993, 1996) work on the incentive limits of internal organization, particularly his notion of "the impossibility of selective intervention. Williamson (1985: chapter 6) refers to the "chronic puzzle" of the determinants of the optimum size of firms and their efficient boundaries. His take on the issue begins from asking, "Why can't a large firm do everything that a collection
} 


\section{Credible Delegation}

\section{Framing the Problem of Credible Delegation}

In game theory parlance, credible delegation obtains when it is a dominant strategy for managers to not intervene in the discretion that they have delegated to employees, and this is common knowledge (in the sense of game theory). The ultimate reason why there may be a credibility issue in organizations is that management's promises concerning delegation to employees usually cannot be enforced by a third party (notably a court). It is important to organizations that such promises are made credible when, if employees trust the promise, they act in ways that are beneficial to the organization.

Parts of the political economy (e.g., Kiser and Barzel 1991) and the organizational economics literatures (Milgrom 1988; Miller 1992; Williamson 1985, 1993; Aghion and Tirole 1997; Baker, Gibbons, and Murphy 1999; Al-Naijjar 2001) provide ways of framing the issue of credible delegation. In particular, Baker, Gibbons and Murphy (1999) provide an attractive game theoretic framing, and as we shall make use of an altered version of their model, we briefly summarize their analysis here.

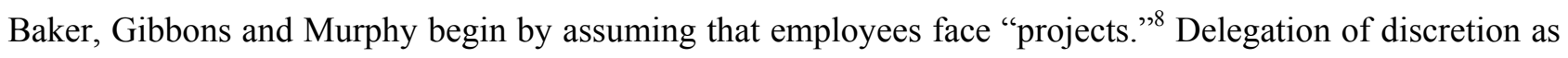
they define it gives employees the informal right to search for and initiate projects. Delegation of discretion is "informal" in the sense that the formal right to ratify remains in the hands of the manager, and cannot be allocated to the employee through a court-enforceable contract (cf. Williamson 1996). Employees can obtain private benefits from some projects, whereas other projects will not yield such benefits. Similarly managers

of small firms can do and more?" The reason why that question is worth asking is that it builds on plausible premises but lead to implausible conclusions, to wit, that all economic activity will be organized in one giant firm. Consider two competing firms. Net gains should always be expected from a merger, because of savings on overheads, economies of scale, coordination of pricing decisions, etc. Little needs to change on the level of organization. What were previously autonomous firms may now be units with semi-autonomous status. Importantly, incentives may be as high-powered as they were prior to integration. The decisions that are most efficiently made at the levels of operations will be made there. "Intervention at the top thus occurs selectively, which is to say only upon a showing of expected net gains" (Williamson 1985: 133). This implies that the combined firm can do everything the stand-alone firms could and more, so that"... integration realizes adaptive gains but experiences no losses" (p.161). Such intervention is, however, "impossible." We add to the reasons given by Williamson for why first-best intervention is in general not feasible. As in Williamson, the effects on organizational value-creation of managerial intervention are examined here. However, unlike Williamson we argue that employee motivation is an important mediator of the relation between managerial intervention and organizational value creation.

8 "Projects" is a metaphor for any activity to which decisions rights may be allocated. 
derive private benefit from some projects, but not from other projects. Managers may or may not have the information that is necessary to assess a project.

The effort that an employee will expend on searching for and starting projects depends on his expected benefits. In turn, these benefits are influenced by the probability of being overruled. Whether overruling takes place depends on the value that employees and managers place on their reputation and on what the manager knows about the projects. Thus, the manager may have all information necessary to ratify a project, but may still decide to delegate discretion (i.e., decision rights) to employees, even if this is not always in the best interests of the manager (or the firm). If this promise is believed, it induces superior effort on the part of the employee with respect to searching for and starting projects. The snag, however, is that while the benefits of increased search etc. may outweigh the costs of bad projects, the manager has the information to assess a particular project, and may be "... tempted to renege on the promise by rejecting a project that is not in her (or the firm's) interest" (Baker, Gibbons and Murphy 1999: 57). However, if the manager values her reputation sufficiently, she will not overrule the employee (as in Klein and Leffler 1981). If the boss is not informed about the project, the situation is different, as the decision to overrule can only be based on the results of the project. In this case, it is the employees' reputation that is at stake rather than that of managers. In these games, many equilibria are feasible, depending on specific assumptions. Thus, the particular equilibrium that emerges will be determined by the discount rates and the trigger strategies followed by the players (e.g., will the employee lose trust in the manager for all future periods, or only in some, if he is overruled?), as well as how they value they reputation For some values of these variables, an equilibrium with credible delegation can be sustained. Thus, credible delegation takes place through self-enforcing relational contracts. 


\section{A Simple Model}

Like Baker, Gibbons and Murphy, we explore the possibility of sustaining delegated discretion in equilibrium. We build a very simple model in order to keep the complexity of our argument manageable. ${ }^{9} \mathrm{We}$ later use the model to reason about how organizational design variables may sustain delegated discretion.

Benefits. Benefits from employee actions may accrue to employees, managers, and organizations. ${ }^{10}$ In addition to a fixed salary, the main utility source for an employee is to have discretion delegated to him. ${ }^{11}$ Employees that are given discretion experience an increase in their intrinsic motivation which gives rise to higher rates of work effort and investments in human capital (i.e., learning). This gives rise to organizationlevel benefits, as overall productivity and learning investments increase. However, these benefits show up at a later time. Specifically, if delegation is undertaken in period 1, firm-level benefits are realized in period 2. For example, delegation may lead to incremental process innovations (period 1) that are implemented and only show their effects later (period 2).

Managers are rewarded directly on the basis of their measurable results. These results appear in period 1, and arise when managers implement projects (whether initiated by employees or managers themselves) that improve organizational effectiveness in the area of their responsibility. Managers can sometimes produce fast and easy-to-measure results by intervening, for example, to curb slack (which may have impact on costs). However, intervening managers may fail to take into consideration how intervention de-motivates employees and how this reduces the long-term benefits to the firm stemming from improved motivation and investments in human capital that delegation of discretion may cause. Apart from ignorance and neglect, managers may

\footnotetext{
${ }^{9}$ In addition to being simpler, our model differs in various ways from that of Baker, Gibbons, and Murphy (1999), for example, by including organizational benefits.

10 "Firms benefits" are the residual income stream that is left over when managers and employees have been paid. We assume that this income stream is appropriated by shareholders. We adopt a shareholder perspective, such that the entity that has an interest in making delegation credible is the "firm" (i.e., the shareholders). However, our model is such that when credible delegation maximizes shareholder value, it also maximizes the total value created in the firm (including the employees' private benefits from delegation).

${ }^{11}$ This is clearly "unrealistic" in the sense that employees do not always like getting more discretion. This limits the scope of the analysis to situations where employees are in fact intrinsically motivated by discretion.
} 
do this because such benefits cannot easily be attributed to the actions taken by managers or because managers expect to be job-rotated within the organization, get a job in a different organization, retire, etc.

Interaction. Figure 1 provides a representation of the interaction between a representative employee and a representative manager. It maps organizational benefits and the benefits of the employee and the manager in two periods, depending on whether intervention does or does not take place.

\section{[Insert Figure 1 here]}

Projects and search. If in period 1 the employee is given discretion, he engages in search for a project at a personal costs, $\mathrm{c}(\mathrm{e})=\beta \mathrm{e}$, where e is employee effort in searching and $\beta$ is a variable search costs coefficient that depends on organizational design variables. The intuition behind this is that, for example, a workflow structure reduces the costs of mutual adjustment and thereby makes (some kinds of) search less costly.

The employee can discover two types of projects that are distinguished according to their organizational benefits (cf. figure 1). Thus, there is one type of project that yields benefits (y) to the organization in terms of, for example, improved coordination of activities, improved products, etc. and another type that destroys value (-y), for example, because it leads to overuse of common pool resources (Vining 2003), cannibalization of market share, etc. The probability (a) that an employee discovers a project with value y is a positive function of the amount of search (e) he engages in. Specifically, it is assumed that a $=\sqrt{ }$ e where 0 $>\mathrm{e} \geq 1$. The employee is motivated to engage in search, because he derives utility ( $\mathrm{y})(0<\mathrm{t} \leq 1)$ from discovering new projects. ${ }^{12}$ Moreover, the employee can be given a performance pay $(\mathrm{m})$ contingent on the discovery of a project with a positive y value.

The manager himself can also engage in search and implementation of projects. For example, he can search for product ideas, as well as search for ways of eliminating slack in the organization. We assume that the manager only seizes the initiative in this manner after overruling the employee (cf. Figure 1). The projects that the manager discovers yield $\mathrm{k}$ benefits to the firm ( $\mathrm{k}$ can be negative). His search costs are $\mathrm{C}(\mathrm{E})=\varphi \mathrm{E}$,

\footnotetext{
${ }^{12}$ We make the simplifying assumption that employees derive the same benefit from any project they may discover.
} 
where $\varphi$ is a search costs coefficient. As will be explained later, $\varphi$ depends on organizational design variables. E is the manager's effort in searching. The probability (b) that a manager discovers a project with $k$ is a positive function of the amount of search (E) he engages in. We assume that $b=\sqrt{ } E$, where $0>E \geq 1$.

A manager has an incentive to engage in search, because he only receives a bonus if either he himself or the employees under his supervision improve the performance of the firm. If the employee discovers a project with value $\mathrm{y}$, the manager receives ry $(0<\mathrm{r} \leq 1)$ benefits. If the manager discovers a project with value $\mathrm{k}$, he receives benefits amounting to rk. For simplicity, we assume that the manager's motivation is purely extrinsic.

As explained earlier, managers intervene either by overruling projects or by substituting coordination mechanisms with much delegated discretion with ones with less delegation. In both cases, the employee will experience a decrease of motivation, and the firm will loose those motivation-dependent benefits that are realized in period 2. We first examine situations in which the manager overrules projects and then turn to situations in which the manager substitutes coordination mechanisms that imply much delegated discretion with ones that imply less delegation.

\section{Commitment and Non-commitment: Different Contracting Environments}

Consider two different environments: One in which the manager can write an enforceable contract with the employee that commit him to not overrule projects, and another where such a contract cannot be written.

An enforceable contract to not overrule projects can be written. The employee expends effort on search until he equates the marginal costs and the marginal benefits of search. The employee's search costs are $\beta \mathrm{e}$, and when $\mathrm{e}$ is substituted with a, this becomes $\beta \mathrm{a}^{2}$ The employee's expected benefits are am + ty. Differentiating this with respect to a, we find that the probability (a) that the employee discovers a project with a positive y value can be expressed as $\mathrm{a}=\mathrm{m} / 2 \beta$. Denote this probability $\hat{a}^{13}$

\footnotetext{
${ }^{13}$ We assume that the effort expended by an employee on performance pay is greater than the effort expended by an employee who is not on performance pay. An employee with no performance pay will expend effort amounting to $(1 / 2 \beta)^{2}$, whereas an employee on performance pay will expend effort amounting to $(\mathrm{m} / 2 \beta)^{2}$.
} 
The expected benefits to the firm from employee search are: $\hat{a}(x+y)+(1-\hat{a})(x-y)$. The first term represents the expected value to the firm from the employee discovering a project with a positive value $y$. When the employee discovers a project with a positive y value, he will not be overruled and the firm will realize the benefit of the project plus the benefits from the intrinsic motivation that emerge in the second period. The second term represents the expected value to the firm from having the employee discover a project with a negative y value. Since the employee will not be overruled, the firm will realize a loss from implementing the project but will also realize the positive benefits from the intrinsic motivation that arise in the second period. The expected benefits to the manager from writing an enforceable contract to not overrule projects are: âry.

Enforceable contract to not overrule projects cannot be written. In this situation the manager overrules the employee when the latter discovers projects with negative y values. ${ }^{14}$ Since the employee's expected benefit from search is $\mathrm{a}(\mathrm{m}+\mathrm{t} \mathrm{y})$, the probability (a) that the employee discovers a project with a positive $\mathrm{y}$ value can be expressed as $a=m+t y / 2 \beta$. This probability is denoted $a^{*}$, where $a^{*}>\hat{a}$, because the employee expends more effort on search compared to the situation where an enforceable contract not to intervene could be written. ${ }^{15}$

When a manager overrules a project, he expends effort on search (recall that overruling is defined as the manager taking over the search task). The managers' search costs are $\varphi \mathrm{E}$ and his expected benefits from search are brk. When $\mathrm{E}$ is substituted with $\mathrm{b}$, and the functions are differentiated with respect to $\mathrm{b}$, we find that the probability (b) that the manager discovers a project with a positive $\mathrm{k}$ value can be expressed as $\mathrm{b}=\mathrm{r}$ $\mathrm{k} / 2 \varphi$. We denote this probability $\mathrm{b}^{*}$. The manager's optimal search cost is $E^{*}=(\mathrm{rk} / 2 \varphi)^{2}$.

The total expected benefits to the firm from the employee's and the manager's search are: $a^{*}(x+y)+(1-$ $\left.a^{*}\right)\left(k b^{*}-k\left(1-b^{*}\right)\right)$. The first term represents the expected value to the firm from the employee discovering a

\footnotetext{
${ }^{14}$ Managers will not overrule projects that have a positive y value when $\mathrm{r} y>\mathrm{rk} \mathrm{b}^{*}-\mathrm{E}^{*}$. This inequality is assumed to hold in the following.

${ }^{15}$ The intuition behind this paradoxical result is that if employees risk being overruled, they will take explicit account in calculating their optimal search of the benefits that stem from intrinsic motivation. If they do not risk being overruled, they will receive these (fixed) benefits anyway, and they will therefore not influence choice on the margin.
} 
project with a positive value $\mathrm{y}$ and the second term represents the expected value to the firm from the manager engaging in search when the manager overrules the employee, because the project discovered by the employee had a negative y value. The expected benefits to the manager will be: $a^{*} r$ y $+\left(1-a^{*}\right)\left(\mathrm{rk} \mathrm{b}^{*}\right.$ $\left.-\mathrm{E}^{*}\right)$

We now examine the conditions under which managers can commit 1) not to overrule projects and 2) not to substitute coordination mechanisms that allow for much delegation with ones that allow for less delegation.

Creating managerial commitment to not overrule projects. It is beneficial to the firm if a manager can commit not to overrule projects when: $a^{*}(x+y)+\left(1-a^{*}\right)\left(k b^{*}-k\left(1-b^{*}\right)\right)<\hat{a}(x+y)+(1-\hat{a})(x-y)$. Managers can commit not to intervene when: â $r y>a^{*} r y+\left(1-a^{*}\right)\left(r k b^{*}-E^{*}\right)$. The following expression is reached by rearranging terms $\left(\hat{\mathrm{a}}-\mathrm{a}^{*}\right) \mathrm{r}$ y $>\left(1-\mathrm{a}^{*}\right)\left(\mathrm{r} \mathrm{k} \mathrm{b}^{*}-\mathrm{E}^{*}\right)$ : Since the left hand side is negative $(\hat{\mathrm{a}}<$ $\left.a^{*}\right)$, it follows that the manager's search cost $\left(E^{*}\right)$ must be high relative to his expected benefit from discovering a project of positive $\mathrm{k}$ value in order for him to credibly commit to not overrule projects. High search costs reduce the probability (b) of discovering such projects.

The probability (a) that an employee discovers a project with $y>0$ is independent of search effort when there is no performance pay, because the employee receives the same utility from all projects. When the employee is on performance pay, it has the effect of increasing the manager's expected benefits from having the employee engage in search. However, because â is always less than a* independently of the whether there is performance pay or not, the introduction of performance pay increases the manager's expected benefits more when he cannot commit compared to the situation where he can commit not to intervene. Thus, performance pay makes it more difficult for managers to commit to not overrule projects (ceteris paribus).

Creating managerial commitment to not tighten coordination mechanisms. When managers tighten coordination mechanisms, they reduce delegated discretion. In the following, it is assumed that they decide on implementing a coordination mechanism (e.g., rigid work planning) that only allows employees to exercise very limited discretion. The decision is made prior to period 1, so that employees will not engage in 
search. Employees only implement the project managers identify. The expected benefit to the manager from tightening the coordination mechanisms is: $\mathrm{rk} \mathrm{b}^{*}-\mathrm{E}^{*}$.

It is beneficial to the firm if managers can commit not to tighten coordination mechanisms when $\mathrm{k} \mathrm{b}^{*}-\mathrm{k}(1-$ $\left.b^{*}\right)<a^{*}(x+y)+\left(1-a^{*}\right)\left(k b^{*}-k\left(1-b^{*}\right)\right)$. When terms are rearranged, this inequality can be rewritten as: $k$ $\mathrm{b}^{*}-\mathrm{k}\left(1-\mathrm{b}^{*}\right)<\mathrm{x}+\mathrm{y}$. Managers can commit not to tighten coordination mechanisms when $\mathrm{rk} \mathrm{b}^{*}-\mathrm{E}^{*}<$ $a^{*} r y+\left(1-a^{*}\right)\left(r k b^{*}-E^{*}\right)$ When terms are rearranged this inequality can be rewritten as : $r k b^{*}-E^{*}<r$ y.

The latter inequality suggests that there are several ways in which to commit the manager to not tighten coordination mechanisms. The first way is to raise the positive value y of projects discovered by the employee or to raise the benefits ( $\mathrm{r} y$ ) that the manager receives from implementing such projects. A second way is to somehow increase the manager's search costs (E), and a third way is to reduce the value of projects discovered by the manager $(\mathrm{k})$. All of these changes pull in the direction of making stronger the manager's commitment to not intervene.

\section{Achieving Credible Delegation}

Although abstract treatments, such as Baker, Gibbons and Murphy (1999) and the above model, may provide a basic framing of the fundamental economic mechanisms that are involved in making promises credible, they have certain limitations. Thus, they contain no elaborate explanation of why managers intervene and the motivational effects of this, and they do not detail the mechanisms that organizations may deploy to make delegation credible. Still, the basic insights they convey are useful for framing the overall understanding of how credible delegation may be achieved.

Thus, the Baker, Gibbons, and Murphy treatment suggests that managers' choice of whether to intervene or not depends on their benefits from these strategies, given the way employees are expected to react to the chosen strategy. This suggests that if it is possible to make the strategy of intervention a non-attractive one, rational managers will choose non-intervention. Delegation is credible. As mentioned earlier, Baker, Gibbons and Murphy rely on self-enforcing relational contracts to do the trick. The argument here is 
different, namely that it is possible to change the relative payoff from the intervention and non-intervention strategies by designing the organization in ways that raise the cost to managers or reduce their expected benefits from intervention (relative to a status quo point). In the following, we explore the ways in which this may be accomplished, making use of the logic of the above model throughout.

\section{Credible Delegation through Organizational Design}

\section{The Role of Coordination Failure}

Managers may be defined as those employees that are specialized in synthesizing information from diverse sources (Casson 1994), and who are given decision rights to take actions that, using this information, assure internal coordination (Coase 1937; Simon 1951; Malmgren 1961). Thus, much (if not necessarily all) of the rationale of management is coordination. However, organizational economics research has revealed possible incentive liabilities of the managerial task, such as subgoal pursuit (Williamson 1985) and influence costs (Milgrom 1988). To these problems may be added the reduced motivation and the stifled incentives that may be caused by managerial intervention. Coordination failure may be rooted in delegation of discretion, as explained earlier, and in order to reduce coordination failure managers intervene in the discretion delegated to lower levels of the organization. This suggests that an important means of making delegation of discretion credible is to reduce coordination failure. ${ }^{16}$ Organizational design plays the key role here.

The need for coordination in organizations arises from changes in activities and input. The organizational structure and the coordination mechanisms in use in an organization help ensure coordination. The effectiveness of a coordination mechanism depends on the type of interdependencies, the degree of uncertainty and the type of organization structure in which it is implemented. The creation of a fit between these elements reduces organizational and managerial benefits from intervention. ${ }^{17}$ The argument is

\footnotetext{
${ }^{16}$ In terms of the above model, coordination failure may be interpreted as occurring when employees discover projects with $\mathrm{y}$ values that are less than the expected $\mathrm{k}$ values, where the difference is caused by the project having serious negative externalities (e.g., cannibalizing a part of the existing product portfolio).

17 The notion of fit is one of the more thorny ones in organizational theory (Van de Ven and Drazin 1985). Fit here refers to the constellation(s) of organizational design variables that results in optimal organizational performance, given
} 
summarized in Figure 2.

\section{[Insert Figure 2 here]}

The traditional contingency theory of organizational design (e.g., Galbraith, 1974; Mintzberg, 1983) assumes that the interdependencies and the uncertainty that firms face are largely given. The aim is to choose those organizational structure and coordination mechanisms that best fit the contingencies defined by interdependencies and uncertainty. However, there are other design variables that organizations can manipulate in order to influence the fit between organization structure, interdependences and uncertainty. ${ }^{18}$ For example, organizations may manipulate uncertainty and interdependencies in ways that create a fit to those coordination mechanisms that allow for great degrees of discretion (i.e., goal planning and mutual adjustment). In other words, the aim should be to create a configuration of organizational elements that is stable, because the elements fit each other and which includes coordination mechanisms that are consistent with a high degree of delegation of discretion. In terms of the model in the previous section, this amounts to making k small (e.g., the manager will not gain by implementing other coordination mechanisms).

An alternative way of making delegated discretion credible is to increase managers' costs of intervention (cf. Foss, Foss, and Vazquez 2006). .Design variables such as incentive structures, information systems, and decision procedures can be used as means to make delegation credible. In terms of the model in the previous section, this amounts to increasing the manager's costs of search $(\varphi)$ and implementing projects with value $\mathrm{k}$. These two overall means of making delegation credible (i.e., creating organizational fit and raising managers' cost of intervention) are discussed in the two following sections.

internal constraints (e.g., informational asymmetries), external constraints (i.e., the characteristics of the environment) and overall organizational strategy (i.e., "optimality" should here be understood in a second-best sense).

${ }^{18}$ It may seem odd to argue that the level of uncertainty that an organization faces is influenced by design variables. However, as argued by Tosi (1970) and Child (1982) the conditions of uncertainty are created by the actors themselves and in particular through their choices of activities. For example, if a firm chooses not to carry stocks of an essential input to production, it will need to be concerned with what factors are likely to influence supplies in the short run. If it carries stocks, these uncertainty factors are eliminated. 


\section{Credible Delegation through Organizational Fit}

Coordination mechanisms may be distinguished on the basis of whether they are intended to handle already known interdependencies or interdependencies that are to varying degrees unforeseen. Therefore, the choice of coordination mechanisms should reflect the degree and kind of uncertainty that the organization confronts. While planning of work processes and business plans require that interdependencies are at least partly known, mutual adjustment and direct supervision are rather means of handling unforeseen interdependencies. Goal planning and skill standardization occupies a middle position.

Coordination mechanisms also differ in their capacity to solve the coordination problems that arise from different kinds of interdependencies (Grandori 2001). Thompson (1967) identifies three basic kinds of interdependencies, namely pooled, sequential and reciprocal interdependencies. Pooled interdependencies occur when each task can be carried out separately and with no need for interaction between tasks as long as each task performs adequately. Interdependencies exist because all tasks need to be carried out in order to create the desired result or because there are externalities from the use of common pool resources. With sequential interdependencies one activity needs to be finished before another takes place, or a decision in one unit has to precede decisions made in another unit. Reciprocal interdependencies are characterized by the fact that two or more tasks need to adjust their efforts simultaneously and/or in similar directions.

Different types of interdependencies require different modifications of organization members' behaviours. Pooled interdependencies allow for independent experimentation and learning by doing, because increases in the performance of the system of tasks can be achieved by increasing the performance of each of the tasks individually. ${ }^{19}$ If interdependencies are sequential, more information exchange is needed in order to coordinate activities and individual experimentation within tasks will not necessarily improve the performance of the system of tasks. Finally, if there are strong complementarities between activities, only coherent patterns of change can produce improvements in the overall performance of the system (Milgrom and Roberts 1990)

\footnotetext{
${ }^{19}$ More precisely: Within the boundaries defined by interface standards for individual tasks.
} 
The effectiveness of coordination mechanisms also depends on organizational structure. Organizations can contain functional as well as process-based units. We speak of "functional structures" when the permanent supra-units (i.e., departments) are formed on the basis of functional criteria, and of "process structures" when some or most of the permanent supra units are based on work flow interdependencies. ${ }^{20}$ Mutual adjustment processes are eased in process structures compared to functional structures, because units in process organizations contain the main problem-solving or work flow interdependencies. Process structures are therefore more widely used in organizations that rely on specialization in decision-making (Casson 1994) and where continuous adaptation is required (Burns and Stalker 1961). One way of making delegation of discretion credible is to create conditions under which coordination mechanisms, — notably goal planning and mutual adjustment — that allow for much delegated discretion become the most effective mechanisms for handling interdependencies. We argue that this requires that a fit is created between interdependencies, coordination mechanism, uncertainty, and organization structure.

Creating fit by using goal planning. Goal planning is particularly effective in organizations that are characterized by pooled interdependencies at the level of the organization at which discretion is delegated. Specifically, goal planning will not cause severe coordination failures, because there will be few externalities stemming from employee search. In other words, pooled interdependencies make it more likely that employees will discover projects with positive organizational benefits. This raises managers' expected benefit from not intervening. ${ }^{21}$

Pooled interdependencies can be created in various ways, for example, by investing in small scale equipment, creating buffers between activities, or by increasing unit size. Goal targets can be set so as to eliminate the need for information sharing if interdependencies pertain to knowledge and information needed

\footnotetext{
${ }^{20}$ No organizational structure is completely work flow-based, as there is usually some need for functional specialization of the control activities and the strategic activities of an organization (Galbraith 1995).

${ }^{21}$ If activities are designed so that pooled interdependencies obtain, this can also reduce or eliminate projects with negative $\mathrm{k}$ values, because the realization of projects discovered by managers will then also be less influenced by interdependencies. However, in this situation, managers do not benefit from having a greater understanding of organizational interdependencies compared to employees. It is therefore more likely that employees discover projects where $\mathrm{y}>\mathrm{k}$. This is particularly likely to be the case when firms make extensive use of expert employees.
} 
in decisions (Casson 1994). However, such actions may lead to lost effectiveness in operations and can therefore be perceived of by some managers as coordination failures. It is therefore important that the actions are costly for managers to reverse.

Goal planning is comparatively better than work planning in dealing with pooled interdependencies when decision making takes place under conditions of change and uncertainty. However, some of the means by which organizations can create pooled interdependencies also reduce the uncertainty that an organization faces. For example, investing in buffers and reducing goal targets (see Casson 1994) eliminates certain sources of uncertainty in decision making. In turn, this implies that there will be less need for employees to utilize their discretion on adapting activities to changes. If employees are to discover projects with high y values, these projects are more likely to be the ones that include new products, new production techniques and business practices. ${ }^{22}$ The above reasoning leads to the following proposition:

PROPOSITION 1: Delegation of discretion by means of goal planning is more likely to be credible in organizations that simultaneously have created pooled interdependencies, and have employees with high level of expertise.

When firms make extensive use of goal planning, it is important that there is congruency between goals as goal incongruencies create incentives for managers to intervene and change goals. Employees can perceive of such managerial intervention as overruling. For example, a product development team likely has high goals with regard to optimizing product design, while a purchasing team likely has the goal of reducing costs. The product development team wants specialized components to meet their goal, while the component team wants a large volume of standard components to optimize its bargaining power vis-à-vis suppliers and meet its goal. To the extent that these expectations are not consistent — as seems likely —, a coordination failure obtains. Solving this failure may seem to require a redefinition of the goals of at least one the teams. However, this may be conceived of as an unjustified intervention. Managers can avoid these situations by

${ }^{22}$ This suggests that the issue of external fit (Burton and Obel 2004) may be important for preserving credible delegation. We briefly return to this in the Concluding Discussion. 
creating pooled interdependencies between unit goals, thus allowing each unit to independently set their own operational goals. However, creating such pooled interdependencies sacrifices synergies among units. It is therefore important that units can individually discover projects with high y values, so that managers do not need to intervene to realize the synergies. ${ }^{23}$ Managers' costs of intervening in organizational goals increase if sub-goals are highly complementary, so that goals cannot be changed independently of other goals. Complementarity implies that the $\varphi$ (i.e., the search cost coefficient) in managers' search cost function increases, because managers need to consider more constraints in order to identify the feasible set of changes in organizational goals. Managers will then expend less effort on search, which reduces their expected benefits from intervention. It is possible to create complementarities between unit goals while maintaining pooled interdependencies among units with respect to production activities. To accomplish this, firms can design interface standards that regulate inter-unit interdependencies. The level of delegation of discretion will likely be less compared to organizations that created pooled interdependencies by investing in buffers and have low levels of goal achievements. However, it will also be a more cost effective organization. This reasoning yields the following proposition:

PROPOSITION 2: Delegation of discretion by means of goal planning is more likely to be credible in organizations that have strong goal complementarities between unit goals, while maintaining pooled inter unit interdependencies in activities.

Firms can further support credibility of delegation by being committed to a well-defined, specific strategy. Such a strategy implies less need for changes in the hierarchy of goals. Examples are strategies with a continuous focus on a specific product platform or a low cost strategy that is supported by large sunk costs investments. In sum, a credible - "high-commitment" (Ghemawat 1991) — strategy supported by congruent organizational goals with multiple complementarities helps to make delegation credible. In other words:

\footnotetext{
${ }^{23}$ In turn, this may require that the firm has capabilities that allow it to derive competitive advantage from engaging in such novel activities. Thus, firms can strengthen the credibility of delegation to units if they have made sunk costs investments in such capabilities.
} 
PROPOSITION 3: Delegation of discretion by means of goal planning is more likely to be credible in organizations that have made sunk costs investments in, for example, product development or cost leadership.

Creating fit through mutual adjustment. Mutual adjustment is one of the two coordination mechanisms (the other one being direct supervision) that are best applied to dealing with unforeseen contingencies. Mutual adjustment can be interpreted as a coordination mechanism where employees jointly search for new projects, whereas direct supervision is a situation where one manager searches for a new project that adopt firm activities to changing contingencies (as in Coase 1937; Simon 1951). Making delegation credible here translates into creating an organizational design where mutual adjustment processes will be effective in allowing employees to discover projects with high y values. This is, for example, the case when organizations pursue activities where diverse perspectives enhance problem-solving (Grandori 2001), ${ }^{24}$ or when organizations have a relatively high degree of specialization in knowledge so that adaptation requires communication between organizational members who posses diverse knowledge. Moreover, it must be costly to transfer the different sets of information to higher levels in the organization (Casson 1994). These conditions are most likely to be met when firms faces relatively complex tasks and where variables or constraints change unpredictably.

Organizations can be designed such that managers' incentives to substitute mutual adjustment by direct supervision are reduced. For example, firms can define production tasks in ways that make coordination contingent on the information possessed by more than one person. Thus, increasing the degree of specialization in an organization so that tasks cut across knowledge specialization, work activities and functional activities is a means of creating a continuous need for mutual adjustment. The complexity of the coordination problem also influences the extent to which mutual adjustment is an effective means of coordination. However, as Grandori (2001: 144) points out, one of the "... foremost causes of team failure is

24 Direct supervision is the effective way of adapting to changes if the relevant knowledge is concentrated with a manager, if the decision problem is not too complex, and if orders can be effectively communicated to lower level employees. Direct supervision becomes inefficient (relative to mutual adjustment) when these conditions no longer hold (Grandori 2001). 
the size of the system to be coordinated." This suggests that effective mutual adjustment may require intermediate levels of complexity which can be achieved by making some investments in buffers and by manipulating levels for goal attainment. This suggests the following proposition:

PROPOSITION 4: Delegation of discretion using mutual adjustment is more likely to be credible in organizations that simultaneously have high degrees of specialization among employees, high levels of goal attainment, and few buffers.

However, mutual adjustment processes are notoriously costly in terms of time and decision costs (Miller 1992). Well informed managers may have lower costs of search than employees and may therefore be inclined to revert to direct supervision, harming motivation. This temptation may be counteracted by adopting a process structure in order to reduce employee search costs $(\beta)$. A process structure reduces employee search costs to the extent that information and/or work flow interdependencies are contained within relatively small units. If not all the relevant interdependencies can be contained within units, the basic organizational structure can be supplemented with lateral relationships in the form of task forces or teams that have the responsibility of solving inter-unit coordination problems. When such liaison devices are set up, they makes it less costly to make use of mutual adjustment processes among units. Implementing a process organization and setting up liaison devices, represent often large sunk costs investments and are therefore a means of making managers commit to mutual adjustment processes. Such sunk costs investments makes it less likely that managers who search for an alternative organizational design discovers one where $\mathrm{k}$ is large. This reasoning can be summarized thus:

PROPOSITION 5: Delegation of discretion using mutual adjustment is more likely to be credible in organizations that have implemented a process organization and/or created lateral relationships among units.

Because of the costliness of mutual adjustment, this coordination mechanism should be substituted by plans if managers have sufficient knowledge of the relevant interdependences and if decision makers are faced with rather stable environments. Therefore, if managers wish to make the use of mutual adjustment credible, 
they must commit to expose the organization to intermediate levels of uncertainty. How can this be done? Most obviously, the uncertainty that organization members face is influenced by the strategy pursued by the organization and extent to which an organization has secured long term commitments from important stakeholders or has invested in buffers. Organizations can adopt strategies that are supported by sunk costs investment that commit them to relatively high levels of goal achievement (e.g., just-in-time delivery or TQM) and they can commit not to invest too much in buffers (e.g., by being committed to high financial performance). Moreover, firms that compete on product development and have relatively short term commitments with important stakeholders are likely to face a continuous need for adjustment, one that can be met through mutual adjustment processes.

PROPOSITION 6: Delegation of discretion is more likely to be credible when organizations simultaneously have made large sunk cost investment in strategies that create a situation in which mutual adjustment is the preferred coordination mechanism and) have made large sunk costs investments in adopting a process organization and creating liaison devices.

\section{Other Organizational Design Variables that Can Make Delegation of Discretion Credible}

As suggested earlier, delegation of discretion can be made credible by increasing managers' costs $(\varphi)$ of discovering and implementing projects with positive values of $\mathrm{k}$. Of relevance here are specific decision procedures, information structures and incentive structures. These design variables are to some extent complementary to the choice of organization structure and coordination mechanism, because the efficiency with which they can be utilized depends on these factors.

Formal decision procedures. Defining formal decision procedures that allow employees to influence decisions can be an important means of supporting credible delegation of discretion (Adler and Borus 1996). For example creating formal liaison roles, committees and procedures that allow employees to influence the planning and control process and collecting information, formulating advice and taking part in the choice process (Milgrom 1988) may make decisions to be considered legitimate by the employees because they are seen as procedurally just. To the extent that employees care about procedural justice, it becomes more costly 
for managers to circumvent these processes in order to implement projects that have high $\mathrm{k}$ values. This increases the $\varphi$ in managers' search cost function and thereby reduces their incentives to intervene. Formal decision procedures that allow employees to exert influence on decisions can be implemented in any organization. However, they are more common and more formalized in organizations that have adopted matrix or purer forms of process structures. In other words:

PROPOSITION 7: Delegation of discretion is more likely to be credible in organizations that make use of formal decision procedures that involve employees in decisions than in organizations..

Organizations with matrix or purer forms of process structures are more likely to have such formal decision procedures.

Performance pay. The use of performance pay to employees influences their search in directions that increase the probability that they discover projects with positive y value. In such cases performance pay helps to make delegation credible, because employees will search more intensely for projects that yield performance pay compared to projects that yields only intrinsic benefits to them. Performance pay can also increase employee resistance to intervention and thus raise the $\varphi$ in managers' search cost functions, reducing their incentives to intervene. The strength of these effects depends on whether employees experience strong team effect due to externalities in their performance. If pay is only marginally influenced by employees' own search and project performance, it will only marginally influence the probability that employees discover project with $\mathrm{y}>0$. Likewise, employees' resistance to intervention will be low. Performance pay is therefore more likely to reduce managers' incentives to intervene if the organization has created pooled interdependencies in effort levels and often also in activities. Creating such pooled interdependencies ensures that there are few externalities in performance.

Performance pay is most effective in increasing the probability that employees discover projects with positive $y$ value if managers cannot commit not to overrule projects. This indicates that there is a trade-off between creating commitment to not tighten coordination mechanisms and creating commitment to not overrule projects. When the purpose is to create a commitment to not tighten coordination mechanisms, 
performance pay can be used to align the incentives of managers and employees with respect to achieving goals. This requires that there is a close correlation between the goals and the performance criteria on which employees are rewarded. If there is no such correlation, performance pay will not increase the probability that employees discover projects with high y value. In fact, performance pay can even undermine the effectiveness of, for example, mutual adjustment. When mutual adjustment processes are used, it is important that there is little potential conflict of interest among team members (Grandori 2001). If a team is formed by employees from different units, conflicts of interest may be increased if team members are rewarded according to the performance criteria defined for the units to which they belong. If instead performance criteria can be defined for the team, it can help align interest within the team. However, it is more likely that there will be negative externalities from performance pay in organizations that make use of mutual adjustment processes, since employees who participate in these processes often have different roles to fulfil.

PROPOSITION 8: Delegation of discretion is more likely to be credible in firms that make substantial use of performance pay and have created the proper conditions for making use of goal planning.

Informational distance. Managers' information about the need for coordination and about the solution to coordination problems is also a factor that influences their incentives to intervene, since it will influence the costs to managers of discovering projects with $\mathrm{k}>0$. The design of the information and reporting procedures in the organization impacts on the need for intervention that managers perceive. Reporting systems can be designed to create an informational distance between managers and the employees to whom discretion has been delegated. If a manager understands that because of informational distance, he is not in a position to rationally decide whether to overrule or not, he will not overrule (Aghion and Tirole 1997).

Informational distance can be created by having reporting systems that only allow managers to gain access to limited information, by having information pass multiple hierarchical layers or by increasing the span of control (i.e., the number of employees in a unit for which a unit manager is responsible). If the span of 
control is sufficiently large, detailed supervision will create a heavy work overload for the manager. This is particularly so when there are intensive interdependencies within the unit, many different specialities, and where each member of the unit carries out different activities (Galbraith 1995). These are the same conditions under which mutual adjustment processes are effective in achieving coordination. Thus, under such conditions credible delegation of discretion is reinforced by informational distance.

PROPOSITION 9: Delegation of discretion is more likely to be credible in firms that have created a large informational distance in the hierarchy. The informational distance is likely to be largest in firms that have created the proper conditions for the use of mutual adjustment processes.

\section{Concluding Discussion}

\section{Contribution to Organizational Theory}

The overall contribution of this work has been to argue that there is a neglected incentive dimension to organizational design. Previous work on organizational design has not neglected such dimensions. For example, some work has made use of the notion of opportunism, but has treated it in terms of managerial sub-goal pursuit (Williamson 1985; Burton and Obel 1988) or as rent-seeking (Milgrom 1988). The treatment here rather focuses on managerial reneging on promises, and how the temptation to renege can be controlled, preserving employee motivation. At a fundamental level, it is central to the argument that the particular property rights structure that characterizes the firm fosters problems of credible commitment. In other words, it is inherent in the nature of firm organization that a promise to delegate discretion from managers to employees or from top managers to lower level managers is not in itself credible. Under the property rights structure characterizing the firm, delegated decision rights are always "loaned, not owned" (Baker et al. 1999). Moreover, delegation of discretion is not court-enforceable (Williamson 1996). The attendant commitment problems are the firm-level equivalent of the opportunism problems that may arise in a market setting because of imperfect enforcement.

Our pursuit of this theme and its ramifications have implied a combination of key ideas from sociological 
and psychologically grounded organizational theory with central ideas from organizational economics. Although the basic framing of the discussion comes from organizational economics, we add to this by making use of key ideas on organizational design, notably classical typologies of organizational interdependencies (Thompson 1967) and coordination mechanisms (Mintzberg 1983; Grandori 2001), as well as insights from the organizational behaviour field on employee motivation (Rousseau 1989). Here are some of the insights that emerge from combining these ideas. ${ }^{25}$

No first-best intervention. The analysis in this paper implies that in general, some of the opportunities for value-creating intervention that would obtain in a situation of full information must be forsaken, because the effects of managerial intervention of employee motivation are partly unpredictable. The resulting hands-off recommendation implies that inefficiencies are unavoidable. This adds a new dimension to Williamson's $(1985,1996)$ argument that efficient "selective intervention" is in general not attainable.

Credible delegation without self-enforcing, relational contracts. Baker, Gibbons and Murphy (1999) analyze credible delegation in terms of self-enforcing, relational contracts. However, their treatment is very abstract, and it is not obvious to which organizational phenomena such contracts relate (corporate culture?) and how they can be influenced by managers. Two alternative and arguably more operational ways of making delegation of discretion credible have been treated here. The first one is choose design variables such as performance pay, information structure and decision procedures so that the resistance of employees to intervention is increased. The second one is to create a fit between/stable configuration of coordination mechanisms, interdependencies, uncertainty, and organization structure. Creating such a fit reduces coordination failure in the organization and therefore diminishes the incentives of managers to intervene. ${ }^{26}$

\footnotetext{
${ }^{25}$ On a very basic level, the organizational economics literature has had rather little to say about organizational design issues that cannot be addressed in terms of resolving incentive conflicts. Moreover, this literature treats motivation in a one-dimensional manner, placing all of the emphasis on extrinsic motivation, and neglecting the richness of findings in organizational psychology. Conversely, most of the organizational design literature neglects incentive considerations, placing primary emphasis on information processing and coordination problems.

${ }^{26}$ This argument is based on the assumption that there is a link between the short term benefits to the firm from employees' discretionary activities and the benefit that managers receives in the form of performance pay, promotion or status. It is not obvious in all cases that such a link exists, since even short term improvements can be difficult to
} 
Firms can manipulate organizational design variables to reduce the negative externalities and increase the benefits to the firm of employee discretionary activities. ${ }^{27}$

\section{Future Research}

Theoretical Extensions. This work is not a comprehensive analysis of all relevant aspects of making delegation of discretion credible. The focus has been on some salient characteristics of an organization in which delegated discretion is credible. In contrast, the process by which an organization reaches such a state — including issues of management rhetorics and how employees perceive the process of persuasion they are subject to - has been suppressed. ${ }^{28}$ An obvious limitation is that we have the neglected the way in which an intervention is motivated and communicated to employees. Instead of refraining from intervention, it is conceivable that managers can motivate and communicate an act of intervention to employees in such a manner that loss of motivation is avoided.

However, the analysis in this paper also has implications for a process perspective. Thus, the analysis implies that when organizations make delegation credible at a certain level, it becomes much more costly for managers at higher levels to reallocate discretion to different levels. This has implications for the ability of organizations to react to changes in their environment. For example, sudden changes in the environment may call for top-down coordination of many activities simultaneously. When discretion has been made credible at low levels of the organization, organizations will not only loose intrinsic motivation from such top down coordination, they will also face high costs in terms of, for example, greater employee resistance to the intervention, costs of re-designing the organization, etc.

measure or to attribute to the area of responsibility for one manager. When such a link exists, the aim for the firm is to make sure that the discretionary activities are highly beneficial to the firm rather than ones that destroy value.

${ }^{27}$ An alternative route, which we have not discussed, is to increase managers' share of the short term benefits to the firm. However, if managers are give very strong incentives it also increases their expected benefit from improving the short term performance of the firms - which may make intervention tempting.

${ }^{28}$ For a congenial organizational behavior approach to management credibility, see Simons (2002), and for an approach to the management of organizational justice, see Greenberg (1990). 
The analysis here also harmonizes with process analyses of the growth strategies of organizations in terms of engaging in mergers and acquisitions. Often, organizations need to make great alterations in business practices and in organizational structure in order to realize the potential synergies in mergers and acquisitions. Organizations that have invested in making delegation credible at some level of their organizations may find it more costly to engage in such activities.

Non-design variables. Other variables that are not design variables also influence the credibility of delegation (cf. figure 2). Notably, managers may stake their personal reputations (Miller 1992; Argyres and Mui 1999), for example through symbolic and communicative acts, such announcing in large-scale company gatherings one's firm commitment to certain policies and values (Brockner et al. 1992). However, credible commitments are far from perfect with respect to constraining opportunistic behaviours (Williamson 1996). For example, there is a "last-period problem" (Klein and Leffler 1981), because managers change jobs and may not carry their reputation with them, or may be close to retirement. Moreover, many firms are so large and complex that the informational requirements for the effective working of reputation effects are not met. The effect is to dampen the commitment creating effect of reputations. This reasoning predicts that we would expect relatively more harmful exercise of authority from managers who are about to change jobs or retire or occupy middle-management positions.

Some employees or groups of employee may also be particularly costly for management to overrule, because their discretion is not only formally delegated, but also strongly grounded in the real control of critical resources, notably specialized human capital, ability to charismatic leadership, a favourable reputation with certain customers, etc. Thus, frustrated employees who are in high demand are more likely to be bid away by competitor firms. The costs of overruling employees who control over critical resources increase when they take part in decisions processes or receive performance pay.

Empirical work. There is as yet no empirical work on the full story that we have presented. However, empirical evidence speaks to some of the causal mechanisms we have postulated. For example, there is evidence for the negative motivational impact that managerial intervention has on employee motivation (e.g., 
Robinson 1996). The perhaps most directly relevant empirical work is Foss, Foss and Vázquez (2006). They hypothesize that delegation improves motivation, that managerial intervention harms overall firm performance, but that mechanisms such as managers staking their personal reputation, employees controlling important assets and strong trade unions can keep managerial proclivities to intervene at bay (they concentrate less on organizational design, however). Using path-analysis on a dataset based on 329 firms in the Spanish food and electric/electronic industries, they find support for these hypotheses. We take this to be an empirical indication that the line of inquiry that has been pursued in this paper is a promising one. 


\section{References}

Adler, Paul S. and Bryan Borys. 1996. "Two Types of Bureaucracy: Enabling and Coercive," Administrative Science Quarterly 41: 61-89.

Aghion, Philippe and Jean Tirole. 1997. "Formal and Real Authority in Organization," Journal of Political Economy 105: 1-29.

Al-Najjar, Nabil. 2001. "A Reputational Model of Authority," Journal of Economic Behavior and Organization 46: 165-191.

Argyris, Nicholas and Julia Porter Liebeskind. 1999. "Contractual Commitments, Bargaining Power, and Governance Inseparability: Incorporating History into Transaction Cost Theory," Academy of Management Review 24: 49-63.

Argyris, Nicholas and Vai-Lam Mui. 1999. "A Political-Economic Approach to Organizational Dissent," Working Paper.

Baker, George, Robert Gibbons, and Kevin J. Murphy. 1999. "Informal Authority in Organizations," Journal of Law, Economics and Organization 15: 56-73.

Baliga, B.R. and Alfred M. Jaeger. 1984. "Multinational Corporations: Control Systems and Delegation Issues,” Journal of International Business Studies : 25-40.

Baron, James N. and David M. Kreps. 1999. Strategic Human Resources: Frameworks for General Managers. New York: John Wiley.

Bazerman, Max H. 1994. Judgment in Managerial Decision Making. New York: Wiley.

Birkinshaw, Julian. 1997. "How Multinational Subsidiary Mandates are Gained and Lost," Journal of International Business Studies 27: 467-496

Bolton, Patrick and Joseph Farrell. 1990. "Decentralization, Duplication, and Delay,” Journal of Political Economy 98: 803-826.

Brockner, J., T.R. Tyler, Cooper, and R. Shneider. 1992, "The Influence of Prior Commitment to an Institution on Reactions to Perceived Infairness: The Higher They Are, the Harder They Fall," Administrative Science Quarterly 37: 241-261.

Burns, Tom and G.M.Stalker. 1961. The Management of Innovations, London: Tavistock Publications.

Burton, Richard M. and Børge Obel. 1988. “Opportunism, Incentives, and the M-Form Hypothesis,” Journal of Economic Behavior and Organization 10: 99-119.

Burton, Richard M. and Børge Obel. 2004. Strategic Organizational Diagnosis and Design: The Dynamics of Fit. Boston: Kluwer. 
Casson, Mark. 1994. "Why are Firms Hierarchical?," International Journal of the Economics of Business 1: 47-76.

Child, John. 1982. "Organizational Structure, Environment and Performance: the Role of Strategic Choice," Sociology 6:1-22

Child, John and Rita McGrath. 2001. "Organizations Unfettered: Organizational Form in an Information Intensive Economy," Academy of Management Journal 44: 1135-1148.

Coyle-Shapiro, Jackie and Ian Kessler. 2000. "Consequences of the Psychological Contract for the Employment Relationship: a Large Scale Survey,” Journal of Management Studies 37: 903-930.

Crozier, Michel. 1964. The Bureaucratic Phenomenon. Chicago: University of Chicago Press.

Deci, Edward. 1975. Intrinsic Motivation. New York and London: Plenum Press.

Foss, Kirsten, Nicolai Foss and Xosé H. Vázquez. 2006. “'Tying the Manager's Hand: Constraining Opportunistic Managerial Intervention,” forthcoming, Cambridge Journal of Economics.

Foss, Nicolai J. 2001. "Leadership, Beliefs and Coordination," Industrial and Corporate Change 10: 357 388.

Foss, Nicolai J. 2003. "Selective Intervention and Internal Hybrids: Interpreting and Learning from the Rise and Decline of the Oticon Spaghetti Organization," Organization Science 14: 331-349.

Gagné, Maryléne and Edward L. Deci. 2005. "Self-Determination Theory and Work Motivation,” Journal of Organizational Behavior 26: 331-362.

Galbraith, Jay R. 1974. “Organization Design: An Information Processing View,” Interfaces 4: 28-36.

Galbraith, Jay R. 1995. Designing Organizations. San Francisco: Jossey-Bass Publishers.

Ghemawat, Pankaj. 1991. Commitment. New York: Free Press.

Gibbons, Robert. 1999. "Taking Coase Seriously,” Administrative Science Quarterly 44: 145-157.

Grandori, Anna. 2001. Organizations and Economic Behaviour. London: Routledge.

Greenberg, J. 1990. "Looking Fair vs Being Fair: Managing Impressions of Organizational Justice,” Reseach in Organizational Behavior 12: 111-157.

Heath, Chip, Marc Knez, and Colin Camerer. 1993. "The Strategic Management of the Entitlement Process in the Employment Relationship," Strategic Management Journal 14: 75-93.

Hendry, John. 2002. "The Principal's Other Problem: Honest Incompetence and the Specification of Objectives," Academy of Management Review 27: 98-113. 
Hill, K.G. and T. M. Amabile. 1993. "A Social-Psychological Perspective on Creativity: Intrinsic Motivation and Creativity in the Classroom and Workplace," in S.G. Isaksen, M.C. Murdoch, R.L. Firestien, and D.J. Treffinger. 1993. Understanding and Recognizing Creativity. Norwoord, NJ: Ablex.

Holmström, Bengt. 1999. “The Firm as a Subeconomy,” Journal of Law, Economics, and Organization 15: 74-102

Jensen, Michael C. and William H. Meckling. 1992. "Specific and General Knowledge and Organizational Structure," in Lars Werin and Hans Wijkander, eds. 1992. Contract Economics. Oxford: Blackwell.

Kaplan, Sarah and Rebecca Henderson. 2005. "Inertia and Incentives: Bridging Organizational Economics and Organizational Theory," forthcoming, Organization Science.

Kerr, Stephen. 1975. "On the Folly of Rewarding A, While Hoping for B," Academy of Management Journal 18: 769-783.'

Kiser, Edgar and Yoram Barzel. 1991. "The Origins of Democracy in England," Rationality and Society 3: 396-422.

Klein, Benjamin. 1991. "Organizational Capital and the Theory of the Firm," in Oliver E. Williamson and Sidney G. Winter, eds. 1991. The Nature of the Firm. Oxford: Basil Blackwell.

Klein, Benjamin and Keith Leffler. 1981. "The Role of Market Forces in Assuring Contractual Performance," Journal of Political Economy 89: 615-641.

Kouzes, J.M. and B.Z. Posner. 1993. Credibility: How Leaders Gain and Lose it. San Francisco: JosseyBass.

Lawrence, Paul R. and Jay W. Lorsch. 1967. Organization and Environment. Boston.

Lindenberg, Siegwart. 2001. "Intrinsic Motivation in a New Light," Kyklos 54: 317-342.

Lindenberg, Sigward. 2003. "The Cognitive Side of Governance," Research in the Sociology of Organizations 20: 47-76.

Malmgren, Harold B. 1961. "Information, Expectations, and the Theory of the Firm," Quarterly Journal of Economics 75: 399-421.

Meyer, Alan D., Anne S. Tsui, and C.R. Hinings, C.R. 1993. "Configurational Approaches to Organizational Analysis," Academy of Management Journal 36: 1175-1195.

Milgrom, Paul. 1988. "Employment Contracts, Influence Activities, and Efficient Organizational Design," Journal of Political Economy 96: 42-60.

Milgrom, Paul and John Roberts. 1990. "The Economics of Modern Manufacturing Technology, Strategy and Organization," American Economic Review 80: 511-528 
Miller, Gary. 1992. Managerial Dilemmas. Cambridge: Cambridge University Press.

Friedman, Milton. 1960. A Program for Monetary Stability. Fordham: Fordham University Press.

Mintzberg, Henry. 1983. Structures in Fives. Englewood Cliffs: Prentice-Hall.

Nickerson, Jackson and Todd Zenger. 2004. "A Knowledge-based Theory of the Firm: The ProblemSolving Perspective," Organization Science 15(6): 617-632

Osterloh, Margit and Bruno Frey. 2000. "Motivation, Knowledge Transfer and Organizational Form," Organization Science 11: 538-550.

Porter, L.W. and Edward E. Lawler, E.E. 1968. Managerial Attitudes and Performance. Homewood, IL: Dorsey Press.

Rivkin, Jan and Nicolai Siggelkow 2003 "Balancing Search and Stability: Interdependencies Among Elements of Organizational Design," Management Science 49: 290-311.Roberts, John. 2004. The Modern Firm. Oxford: Oxford University Press.

Robinson, Sandra L. 1996. "Trust and Breach of the Psychological Contract," Administrative Science Quarterly 41: 574-599.

Robinson, Sandra L. and Denise M. Rousseau. 1994. "Violating the Psychological Contract: Not the Exception but the Norm," Journal of Organizational Behavior 15: 245-259.

Robinson, Sandra L. and Elizabeth Wolfe Morrison. 1995. "Psychological Contracts and OCB: The Effects of Unfulfilled Obligations on Civic Virtue Behavior," Journal of Organizational Behavior 16: 289298.

Rousseau, Denise M. 1989. "Psychological and Implied Contracts in Organizations," Employee Responsibilities and Rights Journal 8: 121-139.

Rousseau, Denise M. and J. McLean Parks. 1993. "The Contracts of Individuals and Organizations," Research in Organizational Behavior 15: 1-43.

Parks, J. McLean. 1997. "The Fourth Arm of Justice,” in B. Lewicki, B. Sheppard, and B. Ries, eds. Research on Negotiation in Organizations, Greenwich, CT: JAI Press: 113-144.

Simon, Herbert A. 1951. "A Formal Theory of the Employment Relationship," in idem. 1982. Models of Bounded Rationality. Cambridge: MIT Press.

Simon, Herbert A. 1962. "The Architecture of Complexity," in Oliver E. Williamson and Scott Masten, eds. 1995. Transaction Cost Economics. Aldershot: Edward Elgar.

Simon, Herbert A. 1973. "The Structure of Ill-Structured Problems," Artificial Intelligence 4: 181-201.

Simon, Herbert A. 1991. “Organizations and Markets,” Journal of Economic Perspectives 5: 25-44. 
Simons, Tony. 2002. "Behavioral Integrity: The Perceived Alignment Between Managers' Words and Deeds as a Research Focus," Organization Science 13: 18-35.

Thomas, K. and B. Velthouse. 1990. "Cognitive Elements of Empowerment: An Interpretive Model and Intrinsic Task Motivation," Academy of Management Review 15: 666-681.

Thompson, James D. 1967. Organizations in Action. New York: McGraw-Hill.

Tosi, H. Aldag and R. Storey. 1970. "On the measurement of the Environment: An Assessment of Lawrence and Lorsch's Environment Uncertainty Scales,” Administrative Science Quarterly 34: 168-189.

Tyler, Tom R. and Steven Blader. 2000. Cooperation in Groups: Procedural Justice, Social Identity, and Behavioral Engagement. Psychology Press.

Vining, Aidan. 2003. "Internal Market Failure: A Framework for Diagnosing Firm Inefficiency," Journal of Management Studies 42: 431-457.

Van de Ven, Andrew H. and Delbecq, Andre L. 1976. "Determinants of Coordination Modes Within Organizations," American Sociological Review. 41: 322-338.

Van de Ven, Andrew H. and Robert Drazin. 1985. "The Concept of Fit in Contingency Theory," Research in Organizational Behavior 7: 333-365.

Vroom, V. H. and Jago, A. G. 1988. The New Leadership: Managing Participation in Organizations. Englewood Cliffs, NJ: Prentice Hall.

Williamson, Oliver E. 1985. The Economic Institutions of Capitalism. New York: Free Press.

Williamson, Oliver E. 1993. "Transaction Cost Economics Meets Posnerian Law and Economics," Journal of Institutional and Theoretical Economics 149: 99-118.

Williamson, Oliver E. 1996. The Mechanisms of Governance. Oxford: Oxford University Press.

Woodward, Joan. 1965. Industrial Organization. London: Oxford University Press.

Zenger, Todd. 2002. "Crafting Internal Hybrids," International Journal of the Economics of Business 9: 7996.

Zenger, Todd and William S. Hesterly. 1997. "The Disaggregation of Corporations: Selective Intervention, High-Powered Incentives, and Molecular Units," Organization Science 8: 209-222. 
Figure 1: Timing of Actions and Benefits

Period 1

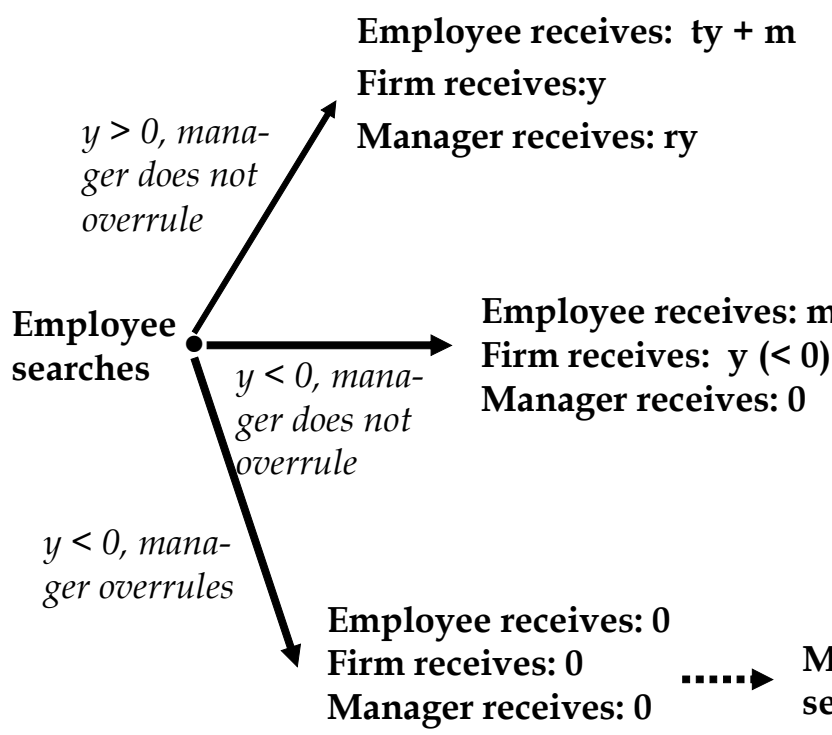

Period 2

Firms receives: $x$

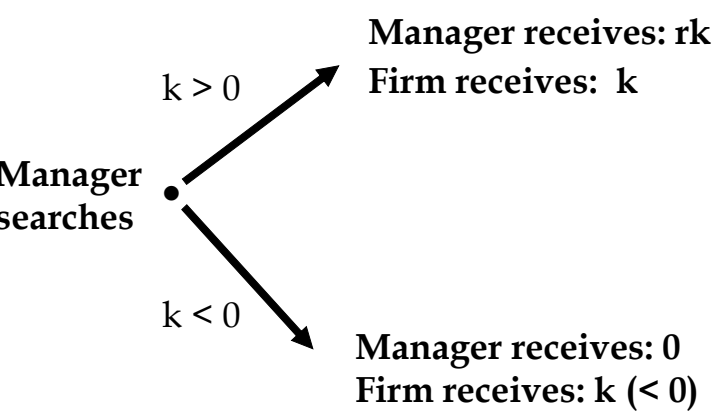


Figure 2: The Overall Argument

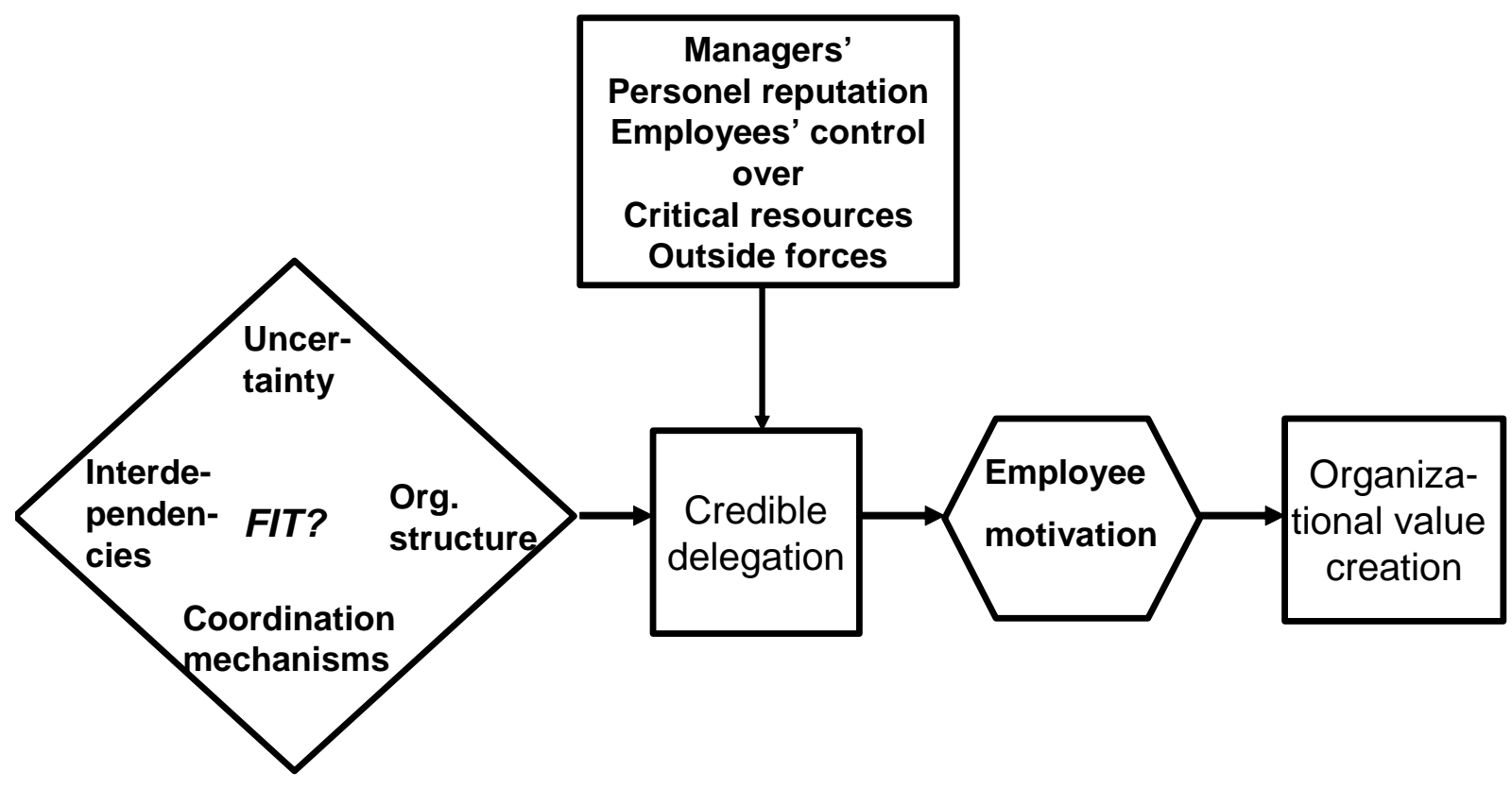




\section{SMG - Working Papers \\ www.cbs.dk/smg \\ 2003}

2003-1: Nicolai J. Foss, Kenneth Husted, Snejina Michailova, and Torben Pedersen: Governing Knowledge Processes: Theoretical Foundations and Research Opportunities.

2003-2: Yves Doz, Nicolai J. Foss, Stefanie Lenway, Marjorie Lyles, Silvia Massini, Thomas P. Murtha and Torben Pedersen: Future Frontiers in International Management Research: Innovation, Knowledge Creation, and Change in Multinational Companies.

2003-3: Snejina Michailova and Kate Hutchings: The Impact of In-Groups and OutGroups on Knowledge Sharing in Russia and China CKG Working Paper.

2003-4: Nicolai J. Foss and Torben Pedersen : The MNC as a Knowledge Structure: The Roles of Knowledge Sources and Organizational Instruments in MNC Knowledge Management CKG Working Paper.

2003-5: Kirsten Foss, Nicolai J. Foss and Xosé H. Vázquez-Vicente: “Tying the Manager's Hands": How Firms Can Make Credible Commitments That Make Opportunistic Managerial Intervention Less Likely CKG Working Paper.

2003-6: Marjorie Lyles, Torben Pedersen and Bent Petersen: Knowledge Gaps: The Case of Knowledge about Foreign Entry.

2003-7: Kirsten Foss and Nicolai J. Foss: The Limits to Designed Orders: Authority under "Distributed Knowledge" CKG Working Paper.

2003-8: Jens Gammelgaard and Torben Pedersen: Internal versus External Knowledge Sourcing of Subsidiaries - An Organizational Trade-Off.

2003-9: Kate Hutchings and Snejina Michailova: Facilitating Knowledge Sharing in Russian and Chinese Subsidiaries: The Importance of Groups and Personal Networks Accepted for publication in Journal of Knowledge Management.

2003-10: Volker Mahnke, Torben Pedersen and Markus Verzin: The impact of knowledge management on MNC subsidiary performance: the role of absorptive capacity CKG Working Paper.

2003-11: Tomas Hellström and Kenneth Husted: Mapping Knowledge and Intellectual Capital in Academic Environments: A Focus Group Study Accepted for publication in Journal of Intellectual Capital CKG Working Paper.

2003-12: Nicolai J Foss: Cognition and Motivation in the Theory of the Firm: Interaction or "Never the Twain Shall Meet"? Accepted for publication in Journal des Economistes et des Etudes Humaines CKG Working Paper.

2003-13: Dana Minbaeva and Snejina Michailova: Knowledge transfer and expatriation practices in MNCs: The role of disseminative capacity.

2003-14: Christian Vintergaard and Kenneth Husted: Enhancing selective capacity through venture bases. 


\section{4}

2004-1: Nicolai J. Foss: Knowledge and Organization in the Theory of the Multinational Corporation: Some Foundational Issues

2004-2: Dana B. Minbaeva: HRM practices and MNC knowledge transfer

2004-3: Bo Bernhard Nielsen and Snejina Michailova: Toward a phase-model of global knowledge management systems in multinational corporations

2004-4: Kirsten Foss \& Nicolai J Foss: The Next Step in the Evolution of the RBV: Integration with Transaction Cost Economics

2004-5: Teppo Felin \& Nicolai J. Foss: Methodological Individualism and the Organizational Capabilities Approach

2004-6: Jens Gammelgaard, Kenneth Husted, Snejina Michailova: Knowledge-sharing Behavior and Post-acquisition Integration Failure

2004-7: Jens Gammelgaard: Multinational Exploration of Acquired R\&D Activities

2004-8: Christoph Dörrenbächer \& Jens Gammelgaard: Subsidiary Upgrading? Strategic Inertia in the Development of German-owned Subsidiaries in Hungary

2004-9: Kirsten Foss \& Nicolai J. Foss: Resources and Transaction Costs: How the Economics of Property Rights Furthers the Resource-based View

2004-10: Jens Gammelgaard \& Thomas Ritter: The Knowledge Retrieval Matrix: Codification and Personification as Separate Strategies

2004-11: Nicolai J. Foss \& Peter G. Klein: Entrepreneurship and the Economic Theory of the Firm: Any Gains from Trade?

2004-12: Akshey Gupta \& Snejina Michailova: Knowledge Sharing in Knowledge-Intensive Firms: Opportunities and Limitations of Knowledge Codification

2004-13: Snejina Michailova \& Kate Hutchings: Knowledge Sharing and National Culture: A Comparison Between China and Russia

\section{5}

2005-1: Keld Laursen \& Ammon Salter: My Precious - The Role of Appropriability Strategies in Shaping Innovative Performance

2005-2: Nicolai J. Foss \& Peter G. Klein: The Theory of the Firm and Its Critics: A Stocktaking and Assessment

2005-3: Lars Bo Jeppesen \& Lars Frederiksen: Why Firm-Established User Communities Work for Innovation: The Personal Attributes of Innovative Users in the Case of Computer-Controlled Music

2005-4: Dana B. Minbaeva: Negative Impact of Hrm Complementarity on Knowledge Transfer in Mncs

2005-5: Kirsten Foss, Nicolai J. Foss, Peter G. Klein \& Sandra K. Klein: Austrian Capital Theory and the Link Between Entrepreneurship and the Theory of the Firm 
2005-1: Nicolai J. Foss: The Knowledge Governance Approach

2005-2: Torben J. Andersen: Capital Structure, Environmental Dynamism, Innovation Strategy, and Strategic Risk Management

2005-3: Torben J. Andersen: A Strategic Risk Management Framework for Multinational Enterprise

2005-4: Peter Holdt Christensen: Facilitating Knowledge Sharing: A Conceptual Framework

2005-5 Kirsten Foss \& Nicolai J. Foss: Hands Off! How Organizational Design Can Make Delegation Credible 